\title{
IMPACT OF LAND LEVELING AND CUT-OFF IRRIGATION ON COTTON YIELD AND WATER PRODUCTIVITY IN NORTH MIDDLE NILE DELTA REGION
}

\author{
M. A. Aiad and Azza A. M. El-Hendawy
}

(1) Soils, Water and Environment. Research Institute, Agriculture Research Center, Giza, Egypt.

(2) Agronomy Research Section, Cotton Research Institute, Agriculture Research Center, Giza, Egypt.

Received: Dec. 12,2020

Accepted: Dec. 31,2020

ABSTRACT: A field trial was conducted through successive the two summer growing seasons 2018 and 2019 at Sakha Agricultural Research Station Farm, Kafr-El-Sheikh Governorate. The objective of this current study was to investigate the impact of three land leveling levels and three irrigation treatments on some water relationships, cotton yield and also some its components. The experiments were designed as split plot with three replications. The main plots were occupied by land leveling with three levels namely; traditional leveling farmers practices (L1), Dead level $(0.0 \%)$ slope (L2) and $0.10 \%$ ground surface slope (L3). while sub plots were devoted t cut-off irrigation with three level namely, cut-off at $100 \%$ of furrow length (I1), cut-off irrigation at $90 \%$ of furrow length (12) and cut-off irrigation at $80 \%$ furrow length(13).

The main results can be summarized as follows:

Land leveling and cut-off irrigation treatments have highly significant effect on increasing the cotton yield. its components and fiber technological properties. The interaction between the two factors resulted in the highest values of cotton yield i.e.

The highest mean values of seed cotton yield, boll weight, leaf area, plant height, lint percentage, lint index and seed index were obtained under $I_{3}$ and $L_{3}$

The highest mean values of fiber fineness, fiber strength, length $2.5 \%$, length $50 \%$ and uniformity index were obtained from interaction between $I_{3}$ and $L_{3}$.

Cut-off irrigation at $80 \%$ from furrow length $\left(I_{3}\right)$ and $0.1 \%$ ground surface slope $\left(L_{3}\right)$ decreased seasonal applied water, water consumptive use and water stored in the effective root zone by $20.11,12.11$ and $10.90 \%$, respectively compared with cut-off irrigation at $100 \%$ of furrow length $\left(I_{1}\right)$ and $L_{1}$ (traditional land leveling). Also, the highest mean values of water application efficiency, water consumptive use efficiency $\mathbf{( 7 1 . 6 5 ,}$ $67.84 \%)$ respectively were obtained with $I_{3}$ and $L_{3}$ treatments.

The highest mean values of water productivity (WP) and productivity of irrigation water (PIW) were recorded under the $I_{3}$ and $L_{3}$.

Key words: Irrigation, land leveling, cotton.

\section{INTRODUCTION}

Today, agriculture sector in Egypt is facing a complex challenge of producing more food with less water the demand for food is driven primarily by population growth which expected to increase from $92 \mathrm{~m}^{3}$ billion in 2016 to 150 billion in year 2050 water is already a limiting factor for agriculture production climate change is likely to enhance the water requirements due to temperature increase whish will in turn amplify the water scarcity thus there will not be enough water to produce the food needed it is therefore imperative to develop and promote water saving practices on large scale in agriculture to 
cope with water scarcity. (Amer et al 2017). Cotton is considered the main cash profitable crop and represents the back bone of agricultural economy as it is the main exported crop as well as its demanded for local industrial uses. Cotton productivity is affected by several factors; e.g. soil practices and irrigation management.

Management of irrigation water and improving soil productivity in Egypt become necessary in order to face water shortage as well as increasing population. New techniques and innovations must be found out to save irrigation water and increase crop production among of these in novation are land leveling and cut-off irrigation.

Irrigation is generally defined as the application of water to soil for the purpose of supplying the moisture essential for plant growth. Efficient use of irrigation water is an obligation of each user. However, use efficiency will vary from locality to another. In areas where water is scarce and costly, available water should be used carefully.

Precision land leveling recorded a positive effect on seed cotton yield (EIMowelhi, et al. 1996). Eid et al (1988) showed that, land leveling with $0.1 \%$ slope increased seed cotton yield $21.5 \%$ than surrounding field under traditional leveling.

$\begin{array}{cccc}\text { Semaika and } & \text { Rady (1987) } \\ \text { recommended that precision land }\end{array}$ leveling program in Egypt increased irrigation efficiencies. Saied (1992) concluded that water consumptive use and amount of irrigation water applied was decreased by $0.1 \%$ ground surface slope and irrigation discharge of $1.0 \mathrm{~m}^{3}$ I min. El-Shahawy (2004) stated that the $0.1 \%$ ground surface slope seemed to be more efficient than traditional land leveling in increasing the cotton yield and its components.
Aiad (2007) found that, the $0.1 \%$ ground sur ere face slope resulted in increasing the cotton yield and its components by $27.43 \%$ compared with traditional land leveling. El-Sanat (2018) stated that the ground surface slope of $0.1 \%$ and $0.05 \%$ and dead land leveling lead to increasing the seed cotton yield by $21.8,15.12$ and $5.15 \%$ compared to traditional land leveling. Precision land leveling using laser assisted land leveler equipped with drag scrapper is a process of smoothing the land surface within +2 $\mathrm{cm}$ of its average micro-elevation. It is contemplated that laser levelers may play a significant role in improving resource use efficiency under surface irrigated system. Improvement in operational efficiency (Rajput et al. 2004), weed control efficiency (Jat et al 2004) reported as a result of precision land leveling when compared to traditional practice of land leveling. Significant increase in water use efficiency (WUE) on laser level fields has been reported by several researchers under different soil and climatic conditions (Jat et al. 2011).

Enhancement in irrigation practices lead to more uniform water distribution, soil and water conservation and economic viability of irrigated agriculture.Thus efficient on farm irrigation methods is necessary for increasing crop production per unit of water applied (Streilkoff et al. 1999; Bautista et al. 2009; Morris et al. 2015 and Anwar et al. 2016, the maximum value of seed cotton yield was ( $1846.3 \mathrm{~kg} \mathrm{fed}^{-1}$ ) was achieved by using gated pipes under furrow length treatments Mohamed et al. (2017). The highest seed cotton yield (5707 kg ha-1), was reached with $130 \%$ ETC and $210 \mathrm{kgN} \mathrm{ha}^{-1}$. The maximum $\mathrm{N}$ agronomic efficiency was achieved at $140 \mathrm{kgN} \mathrm{ha}^{-1}$. The treatments of $10 \%$ ETC showed significant benefits in terms of 
irrigation water savings with $0.587 \mathrm{~kg} \mathrm{~m}^{-3}$ (Zonta et al. 2016).

Cotton production is adversely affected by water stress (Pettigrew, 2004; Dagdelen et al. 2006; Basal et al. 2009). On the other hand, over-irrigation of cotton can cause undesired excessive vegetative growth which may reduce cotton yields (Karam et al. 2006) knowing the optimum water requirement of irrigated cotton is essential to achieving a balance between vegetative and reproductive growth in cotton.

The main objectives of this present study were to

1- Investigate the impact of levels of land leveling on cotton yield, yield components and some technological characteristics.

2- Study the impact of land leveling on some water relationships.

3- Study the influence of cut off irrigation treatments on cotton yield its components some technological characteristics and some water relationships.

\section{MATERIALS AND METHODS}

A field investigation was conducted at Sakha Agricultural Research Station farm Kafr El-Sheikh Governorate, Egypt during two consecutive summer seasons (2018 and 2019). The site lies at 134 km North Cairo and has an elevation of about 6 meters above mean sea level with coordinates of $31^{\circ} 07 \mathrm{~N}$ Latitude $30^{\circ} 57 \mathrm{E}$ longitude. The objective was to study the effect of three land levels; traditional (L1), dead level (L2) $(0.0 \%)$ slope and $0.1 \%$ ground surface slope and three irrigation treatments; traditional irrigation like practice by local farmers (I1, traditional practice), $90 \%\left(I_{2}\right)$ and $80 \%\left(I_{3}\right)$ from furrow length on some water relations, as well as cotton yield and its components.
An experiment was conducted in a split plot design, with three replications. The plot area was $2000 \mathrm{~m}^{2}\left(20 \times 100 \mathrm{~m}^{2}\right)$ for land level treatments, while it was $600 \mathrm{~m}^{2}(6 \times 100 \mathrm{~m})$ for cut-off irrigation treatments. The main plots were assigned to land leveling, with three levels namely $L_{1}, L_{2}$ and $L_{3}$. while the subplots were devoted to cut-off irrigation with three levels namely $I_{1}, I_{2}$ and $I_{3}$.

Cotton (Gossypium barbadebse) Var. Giza 86 cotton seeds were planting in April, 25, 2018 and picked in sept. 30, 2018, while in the $2^{\text {nd }}$ season 2019 the planting date was April, 20 and picking was in Oct. 10, 2019 respectively. Nitrogen, phosphorus and potassium fertilizers were added according to the recommended doses for the crop and area of study. Nitrogen fertilizer was applied in the form of urea $(46 \% \mathrm{~N})$ at the rate of $75 \mathrm{~kg} / \mathrm{fed}$. in two equal doses, the first one before the first post planting irrigation and second one at before the second irrigation. Phosphorus fertilizer in the form of calcium superphosphate $\left(15.5 \% \mathrm{P}_{2} \mathrm{O}_{5}\right)$ was added at the rate of 200 $\mathrm{kg} / \mathrm{fed}$. in one dose before planting during land preparation. Potassium fertilizer in the form of potassium sulphate $\left(48 \% \mathrm{~K}_{2} \mathrm{O}\right)$ at the rate of 50 $\mathrm{kg} / \mathrm{fed}$. was added before planting. The agrometeorological data during the two growing seasons were obtained from Sakha Station as presented in Table 1.

Before performing treatments, soil samples at three depths up to $60 \mathrm{~cm}$ were randomly collected and analyzed for $\mathrm{pH}$, EC according to page et al. (1982). Soil bulk density was determined according to (Blake and Hartage, 1986). Particle size distribution was determined according to Piper, (1950). Some chemical and physical properties of the studied soil are shown in Tables 2 and 3). 
Table 1. Some meteorological data at Kafr El-Sheikh area during the two growing seasons.

\begin{tabular}{|c|c|c|c|c|c|c|c|c|c|}
\hline \multirow[b]{2}{*}{ Months } & \multicolumn{3}{|c|}{ Temperature $\mathrm{C}$} & \multicolumn{3}{|c|}{ Relative humidity\% } & \multirow{2}{*}{$\begin{array}{c}\text { Wind } \\
\text { velocity } \\
(\mathrm{km} / 24 \mathrm{~h})\end{array}$} & \multirow{2}{*}{\begin{tabular}{|c|} 
Pan- \\
evaporation \\
$\left(\mathrm{cm}\right.$ day $\left.^{-1}\right)$ \\
\end{tabular}} & \multirow[b]{2}{*}{$\begin{array}{c}\text { Rain } \\
\mathrm{mm} / \mathrm{month}\end{array}$} \\
\hline & $\operatorname{Max}$ & Mini & Mean & $\operatorname{Max}$ & Mini & Mean & & & \\
\hline & \multicolumn{9}{|c|}{$1^{\text {st }}$ season $(2018)$} \\
\hline Apr. & 27.8 & 20.0 & 23.9 & 80.9 & 43.9 & 62.4 & 74.0 & 0.532 & - \\
\hline May. & 31.2 & 23.8 & 27.5 & 75.6 & 43.9 & 59.8 & 95.8 & 0.634 & - \\
\hline Jun. & 32.6 & 25.3 & 29.0 & 75.5 & 48.0 & 61.8 & 98.6 & 0.771 & - \\
\hline Jul. & 34.2 & 25.4 & 29.8 & 82.6 & 51.0 & 66.8 & 89.5 & 0.737 & - \\
\hline Agus. & 33.9 & 25.2 & 29.6 & 82.4 & 51.4 & 66.9 & 76.0 & 0.642 & - \\
\hline Sept. & 32.8 & 23.5 & 28.2 & 83.1 & 48.3 & 65.7 & 68.7 & 0.498 & - \\
\hline \multirow[t]{2}{*}{ Oct. } & 29.5 & 20.6 & 25.1 & 8.5 & 49.6 & 67.6 & 57.9 & 0.324 & 3.5 \\
\hline & \multicolumn{9}{|c|}{$2^{\text {nd }}$ season (2019) } \\
\hline Apr. & 25.1 & 21.3 & 23.2 & 80.8 & 48.9 & 64.9 & 44.8 & 0.370 & 3.9 \\
\hline May. & 31.9 & 25.4 & 28.7 & 76.4 & 37.9 & 57.2 & 68.4 & 0.683 & - \\
\hline Jun. & 33.0 & 28.0 & 30.5 & 81.5 & 50.0 & 65.8 & 103.0 & 0.846 & - \\
\hline Jul. & 33.5 & 28.4 & 31.0 & 85.2 & 54.4 & \begin{tabular}{|l|}
69.8 \\
\end{tabular} & 83.8 & 0.808 & - \\
\hline Agus. & 34.2 & 28.9 & 31.6 & 89.7 & 55.6 & 72.7 & 68.7 & 0.682 & - \\
\hline Sept. & 32.4 & 27.9 & 30.2 & 83.4 & 52.9 & 68.2 & 76.9 & 0.590 & - \\
\hline Oct. & 30.3 & 26.7 & 28.5 & 87.3 & 54.3 & $\begin{array}{l}70.8 \\
\end{array}$ & 56.6 & 0.384 & 57.3 \\
\hline
\end{tabular}

Table 2. Some chemical properties of the soil before cotton cultivation.

\begin{tabular}{|c|c|c|c|c|c|c|c|c|c|c|c|}
\hline \multirow{2}{*}{$\begin{array}{c}\text { Depth } \\
(\mathrm{Cm})\end{array}$} & \multirow{2}{*}{$\begin{array}{c}\mathrm{EC} \\
\left(\mathrm{dsm}^{-1}\right)\end{array}$} & $\mathrm{pH}$ & $\mathrm{SAR}$ & \multicolumn{3}{|c|}{ Soluble cation meg/L } & \multicolumn{4}{c|}{ Soluble anion meg/L } \\
\hline 0 & 2.20 & $\mathrm{Ca}^{+2}$ & $\mathrm{Mg}^{+2}$ & $\mathrm{Na}^{+}$ & $\mathrm{K}^{+}$ & $\mathrm{Co}_{3}{ }^{-2}$ & $\mathrm{HCO}_{3}$ & $\mathrm{Cl}^{-}$ & $\mathrm{So}_{4}{ }^{-2}$ \\
\hline $0-20$ & 2.78 & 7.86 & 8.28 & 6.8 & 3.5 & 18.8 & 0.5 & - & 1.5 & 14.8 & 13.3 \\
\hline $20-40$ & 3.36 & 8.05 & 9.16 & 7.3 & 5.1 & 22.8 & 0.7 & - & 2 & 17.6 & 16.3 \\
\hline $40-60$ & 4.68 & 8.35 & 10.78 & 9.8 & 7.6 & 31.8 & 0.9 & - & 2.5 & 25.4 & 22.2 \\
\hline Mean & 3.61 & & 9.41 & 7.97 & 5.40 & 24.47 & 0.70 & - & 2.00 & 19.27 & 17.27 \\
\hline
\end{tabular}

Table 3. Some physical properties and some water constants of the soil before cotton cultivation.

\begin{tabular}{|c|c|c|c|c|c|c|c|c|}
\hline \multirow{2}{*}{$\begin{array}{l}\text { Depth } \\
\text { (cm) }\end{array}$} & \multicolumn{3}{|c|}{$\begin{array}{l}\text { Particle size distribution } \\
\text { (\%) }\end{array}$} & \multirow{2}{*}{$\begin{array}{l}\text { Textural } \\
\text { class }\end{array}$} & \multirow{2}{*}{$\begin{array}{c}\text { Bulk } \\
\text { density } \\
\left(\mathrm{Mgm}^{-3}\right)\end{array}$} & \multicolumn{3}{|c|}{ Soil moisture constant (\%) } \\
\hline & Sand & Silt & Clay & & & $\begin{array}{l}\text { Field } \\
\text { capacity }\end{array}$ & $\begin{array}{l}\text { Wilting } \\
\text { point }\end{array}$ & $\begin{array}{l}\text { Available } \\
\text { water }\end{array}$ \\
\hline $0-20$ & 16.38 & 30.85 & 52.77 & Clayey & 1.23 & 43.15 & 23.86 & 19.29 \\
\hline $20-40$ & 15.65 & 30.48 & 53.87 & Clayey & 1.25 & 41.46 & 22.25 & 19.21 \\
\hline $40-60$ & 15.12 & 29.76 & 55.12 & Clayey & 1.33 & 39.25 & 20.18 & 19.09 \\
\hline Mean & 15.72 & 30.36 & 53.92 & Clayey & 1.27 & 41.29 & 22.1 & 19.2 \\
\hline
\end{tabular}


The studied characters were -Plant height $(\mathrm{cm})$

-leaf area $\left(\mathrm{cm}^{2}\right)$

-Seed cotton yield in kentar (157.5

$\mathrm{Kg}$ ) / feddan $\left(4200 \mathrm{~m}^{2}\right)$ : Estimated as the weight of seed cotton yield in kentarl fed.

- Boll weight: The average boll weight in grams of twenty-five bolls picked at random from each treatment.

- Lint percentage (\%): The percentage weight of lint attained from a given weight of seed cotton samples:

Lint percentage $=$ (weight of cotton lint $I$ cotton seed weight) $\times 100$.

Seed index: The weight of 100 seeds in grams.

Lint index $=$ (seed index $x$ lint percentage) I 100 - lint percentage.

Earliness percentage $=($ yield of the first pick / total yield) $\times 100$.

Cotton fiber technological properties:

Fiber fineness, Fiber strength, Length $2.5 \%$, Length $50 \%$ and uniformity

\section{Some water relationships:}

Applied water (AW): Submerged flow orifice with fixed dimension was used to convey and measure the applied water, as the following equation (Michael, 1978).

Where:

$$
\mathrm{Q}=\mathrm{CA} \sqrt{2 g h}
$$

$\mathrm{Q}=$ Discharge through orifice $\left(\mathrm{cm}^{3} \mathrm{Sec}^{-1}\right)$

$\mathrm{C}=$ Coefficient of discharges $(0.60)$

$A=$ Cross sectional area of orifice $\left(\mathrm{cm}^{2}\right)$

$\mathrm{g}=$ Acceleration due to gravity $(980 \mathrm{~cm} \mathrm{I}$ Sec $^{-2}$ )

$\mathbf{h}=$ Pressure head over the orifice center (cm).

-Soil moisture percentage: Soil samples were taken from each $20 \mathrm{~cm}$ depth up to $60 \mathrm{~cm}$ before and after the irrigations to determine moisture content and to calculate the amount of consumed water and stored for each irrigation.
-Water consumptive use (WCU): Was calculated as $\mathrm{m}^{3} \mathrm{fed}^{-1}$ using the following equation (Hansen et al. 1979).

$\mathrm{WCU}=\sum_{i=1}^{i=n} \quad\left\{\left(\frac{\theta 2-\theta 1}{100}\right) \times\right.$ Dbi $\times$ Di $\left.\times 4200\right\}$

Where:

$\Theta_{2}$ : Soil moisture \% after irrigation with 48 hours in the $1^{\text {th }}$ layer

$\theta_{1}$ : Soil moisture $\%$ before next irrigation in the $1^{\text {th }}$ layer

Dbi: Bulk density in $\mathrm{g} / \mathrm{cm}^{3}$ of other $1^{\text {th }}$ layer

i: No of soil layers

$\mathrm{n}$ : No of irrigation and

Di: Soil layer depth $(20 \mathrm{~cm})$

- Stored water was calculated using the following equation: (Hansen et.al, 1979).

$\mathrm{WCU}=\sum_{i=1}^{i=n} \quad\left\{\left(\frac{\theta 2-\theta 1}{100}\right) \times\right.$ Dbi $\times$ Di $\left.\times 4200\right\}$

Where

$\boldsymbol{\theta}_{2}$ : Soil moisture \% after irrigation with 48 hours in the $1^{\text {th }}$ layer

$\theta_{1}$ : Soil moisture \% before the same irrigation in the $1^{\text {th }}$ layer

Dbi: Bulk density in $\mathrm{g} / \mathrm{cm}^{3}$ of other $\mathbf{1}^{\text {th }}$ layer

-Irrigation application efficiency (Ea): It was calculated as described by (Downy, 1970) according to the following equation:

$$
\mathrm{Ea}=\left(\frac{S w}{A w}\right) \times 100
$$

Where:

$\mathrm{Ea}=$ water application efficiency (\%)

Sw $=$ stored water in the root zone

$A w=$ applied water to the field plot

-Consumptive use efficiency (CUE), \%: It was calculated according to (Doorenbos and Pruitt, 1975) as follows:

CUE $=\left(\frac{E T c}{I W A}\right) \times 100$

Where:

ETC: Water consumptive use, and IWA: irrigation water applied to the field $\left(\mathrm{m}^{-3} \mathrm{fed}^{-1}\right)$ during the irrigation.

Water productivity (WP): It was calculated according to Ali et al. (2007). $\mathrm{WP}=\frac{c S Y}{E T}$ 
Where

WP = water productivity ( $\mathrm{kg} \mathrm{m}-1)$,

CSY = cotton seed yield ( $k g$ fed-1) and

ET = total water consumption of the growing season (m3 fed-1).

Productivity of irrigation water (PIW, $\mathrm{kg} / \mathrm{m} 3$ ): Was calculated according to (Ali et al. 2007) as follows:

Where

$$
\mathrm{PIW}=\frac{C S Y}{I}
$$

CSY: cotton seed yield $\left(\mathrm{kg} \mathrm{fed}^{-1}\right)$ and

I: irrigation applied water $\mathrm{m}^{3} \mathrm{fed}^{-1}$

\section{Statistical analysis:}

The data were analyzed statistically by a general linear model procedure and 2way analysis of variance (ANOVA) using Cohort Computer Program according to the method of Gomez and Comez, (1984). Mean separation procedure was performed using LSD's test at a 0.05 and 0.01 level of significance.

\section{RESULTS AND DISCUSSION}

\section{Seed cotton yield:}

The results in Table (4) showed that the seed cotton yield (average of two growing seasons) was significantly affected by land leveling and cut-off irrigation. The interaction between land leveling and cut-off irrigation was significant. The maximum values of seed cotton yield (9.54 kentar $\left.\mathrm{fed}^{-1}\right)$ was obtained with $L_{3}$ ) and (9.48 kentar fed ${ }^{-1}$ ) was recorded under $I_{3}$. While the lowest value of seed cotton yield (8.16 kentar $\mathrm{fed}^{-1}$ ) was obtained with $L_{1}$ and (8.27 kentar $\mathrm{fed}^{-1}$ ) was recorded under litrigation, respectively. The interaction between land leveling and cut-off irrigation had high significant effect on seed cotton yield, respectively. The highest value of seed cotton yield (10.13 kentar $\mathrm{fed}^{-1}$ ) was produced from interaction between cut-off irrigation at $80 \%$ of furrow length and $L_{3}(0.1 \%$ ground surface slope). The results are in a great harmony with those obtained by El-
Shahawy (2014), Aiad, (2001), Zanta et al. (2016), Mohamed et al. (2017) and ElSanat (2018) their results revealed that the ground surface slope of $0.1 \%, 0.05 \%$ and precision land leveling lead to increasing the seed cotton yield by 21.8 , 15.12 and $5,15 \%$ compared to traditional land leveling. It was noticed that the seed cotton yield was increased with decrease cut-off irrigation treatments under land leveling (12 and I3).

\section{Boll weight in (gm):}

The results in Table (5) show that boll weight was significantly affected by land leveling and cut-off irrigation (the average of the two growing seasons). Data also showed that the interaction between land leveling and cut-off irrigation have significant effect on boll weight. The maximum values of boll weight (3.13 and $3.02 \mathrm{gm}$ ) were recorded under $L_{3}(0.1 \%$ ground surface slope) and $I_{3}$ (cut-off irrigation at $\mathbf{8 0 \%}$ of furrow length, respectively. The interaction between land leveling and cut-off irrigation had high significant effect on boll weight, the highest values of boll weight $(3.37 \mathrm{gm})$ was obtained with $I_{3}$ (cut- off irrigation at $80 \%$ of furrow length) under $L_{3}$ (0.1\% ground surface slope). The results are in a great harmony with those obtained by Mohamed et al. (2017) and El-Sanat (2018).

\section{Plant height and leaf area}

The results in Table (4) show that the plant height and leaf area were significantly affected by land leveling and cut-off irrigation in (the average of two growing seasons). Data also showed that the interaction between land leveling and cut-off irrigation had insignificant on plant height and leaf area. The maximum values of plant height and leaf area (155.22 cm and $173.71 \mathrm{~cm}^{2}$ were obtained with $L_{3}$ and $\left(156.55 \mathrm{~cm}\right.$ and $\left.176.43 \mathrm{~cm}^{2}\right)$ were recorded under $I_{3}$, respectively. The highest values of plant height $(159 \mathrm{~cm})$ 
and leaf area $\left(177.43 \mathrm{~cm}^{2}\right)$ were recorded with $I_{3}$ (cut-off irrigation at $80 \%$ of furrow length) under $L_{3}(0.1 \%$ ground surface slope).

Table 4. Seed cotton yield and its components as affected by land leveling and cut-off irrigation treatments (average of two growing seasons.

\begin{tabular}{|c|c|c|c|c|c|c|c|}
\hline Treatments & $\begin{array}{c}\text { Seed cotton } \\
\text { yield } \\
\text { (kentar fed }^{-1} \text { ) }\end{array}$ & $\begin{array}{c}\text { Boll } \\
\text { weight } \\
\text { (gm) }\end{array}$ & $\begin{array}{l}\text { Leaf area } \\
\left(\mathrm{cm}^{2}\right)\end{array}$ & $\begin{array}{c}\text { Plant } \\
\text { height } \\
\text { (cm) }\end{array}$ & \begin{tabular}{|c|} 
Lint \\
percentage \\
$(\%)$ \\
\end{tabular} & $\begin{array}{l}\text { Seed } \\
\text { index } \\
(\mathrm{gm})\end{array}$ & $\begin{array}{l}\text { Lint } \\
\text { index }\end{array}$ \\
\hline \multicolumn{8}{|c|}{ Land leveling (L) } \\
\hline L1 & $8.16 \mathrm{c}$ & $2.61 \mathrm{c}$ & $171.59 \mathrm{c}$ & $149.33 \mathrm{c}$ & $36.73 \mathrm{c}$ & $8.24 \mathrm{c}$ & $4.81 \mathrm{c}$ \\
\hline L2 & $8.97 \mathrm{~b}$ & $2.85 \mathrm{~b}$ & $172.86 \mathrm{~b}$ & $153.66 \mathrm{~b}$ & $37.20 \mathrm{ab}$ & $8.58 \mathrm{~b}$ & $5.07 \mathrm{~b}$ \\
\hline L3 & $9.54 \mathrm{a}$ & $3.13 \mathrm{a}$ & $173.71 \mathrm{a}$ & $155.22 \mathrm{a}$ & $38.34 \mathrm{a}$ & $8.81 \mathrm{a}$ & $5.22 \mathrm{~b}$ \\
\hline$F$ test & ** & ** & ** & ** & ** & ** & ** \\
\hline L.S.D. 0.05 & 0.024 & 0.030 & 0.020 & 1.000 & 0.810 & 0.102 & 0.070 \\
\hline L.S.D. 0.01 & 0.04 & 0.05 & - & 1.67 & 1.35 & 0.17 & 0.11 \\
\hline \multicolumn{8}{|c|}{ cut-off irrigation (I) } \\
\hline I1 & $8.27 \mathrm{c}$ & 2.72 & $169.38 \mathrm{c}$ & $149.33 \mathrm{c}$ & $36.82 \mathrm{c}$ & $8.17 \mathrm{c}$ & $4.96 \mathrm{c}$ \\
\hline 12 & $8.92 \mathrm{~b}$ & 2.85 & $172.36 \mathrm{~b}$ & $152.33 \mathrm{~b}$ & $37.19 \mathrm{~b}$ & $8.58 \mathrm{~b}$ & $5.08 \mathrm{~b}$ \\
\hline 13 & $9.48 \mathrm{a}$ & 3.02 & $176.43 \mathrm{a}$ & $156.55 \mathrm{a}$ & $38.25 \mathrm{a}$ & $8.89 \mathrm{a}$ & $5.33 \mathrm{a}$ \\
\hline$F$ test & ** & ** & ** & ** & ** & ** & ** \\
\hline L.S.D. 0.05 & 0.013 & 0.030 & 0.203 & 1.100 & 0.590 & 0.103 & 0.090 \\
\hline L.S.D. 0.01 & 0.02 & 0.05 & - & 1.54 & 0.83 & 0.04 & 0.12 \\
\hline \multicolumn{8}{|c|}{ Interaction $(L * 1)$} \\
\hline & ** & ** & Ns & Ns & ns & ** & ** \\
\hline
\end{tabular}

Table 5. Cotton fiber technological properties as affected by land leveling and cut-off irrigation treatments (average two growing seasons).

\begin{tabular}{|c|c|c|c|c|c|}
\hline Treatments & Fiber fineness & Fiber strength & Length $2.5 \%$ & Length $50 \%$ & uniformity \\
\hline \multicolumn{6}{|c|}{ Land leveling (L) } \\
\hline L1 & $2.866 \mathrm{c}$ & $9.347 \mathrm{c}$ & $29.281 \mathrm{c}$ & $15.362 \mathrm{~b}$ & 52.46 \\
\hline L2 & $3.508 \mathrm{~b}$ & $9.979 \mathrm{~b}$ & $30.359 \mathrm{~b}$ & $15.924 \mathrm{a}$ & 52.421 \\
\hline L3 & $4.266 \mathrm{a}$ & $10.453 \mathrm{a}$ & $31.48 \mathrm{a}$ & $16.594 \mathrm{c}$ & 52.743 \\
\hline F test & ** & ** & ** & ** & Ns \\
\hline \multicolumn{6}{|c|}{ cut-off irrigation (I) } \\
\hline I1 & $3.074 \mathrm{c}$ & $9.309 \mathrm{c}$ & $28.916 \mathrm{c}$ & $15.278 \mathrm{c}$ & 52.829 \\
\hline 12 & $3.46 \mathrm{~b}$ & $9.94 \mathrm{~b}$ & $30.469 \mathrm{~b}$ & $15.901 \mathrm{~b}$ & 52.188 \\
\hline 13 & $4.104 \mathrm{a}$ & $10.53 \mathrm{a}$ & $31.736 \mathrm{a}$ & $16.702 \mathrm{a}$ & 52.608 \\
\hline$F$ test & ** & ** & ** & ** & Ns \\
\hline \multicolumn{6}{|c|}{ Interaction $(L * 1)$} \\
\hline 1 & $2.467 \mathrm{f}$ & 8.907 & $28.25 \mathrm{f}$ & 14.813 & 52.437 \\
\hline 2 & $2.67 f$ & 9.48 & 28.967 e & 15.147 & 52.287 \\
\hline 3 & $3.46 \mathrm{de}$ & 9.653 & $30.627 \mathrm{c}$ & 16.127 & 52.657 \\
\hline 4 & $3.147 \mathrm{e}$ & 9.227 & 28.767 e & 15.107 & 52.513 \\
\hline 5 & $3.53 \mathrm{~cd}$ & 9.96 & $30.82 \mathrm{c}$ & 15.973 & 51.827 \\
\hline 6 & $3.847 \mathrm{bc}$ & 10.75 & $31.49 \mathrm{~b}$ & 16.693 & 52.923 \\
\hline 7 & $3.62 \mathrm{~cd}$ & 9.793 & $29.73 \mathrm{~d}$ & 15.913 & 53.537 \\
\hline 8 & $4.18 \mathrm{~b}$ & 10.38 & $31.62 \mathrm{~b}$ & 16.583 & 52.45 \\
\hline 9 & $5.007 \mathrm{a}$ & 11.187 & $33.09 \mathrm{a}$ & 17.287 & 52.243 \\
\hline F test & * & Ns & ** & Ns & Ns \\
\hline
\end{tabular}


Lint percentage, lint index and seed index

Presented data in Table (4) clearly showed that values of lint percentage, lint index and seed index were significantly affected by land leveling and cut-off irrigation. The highest values of lint percentage, lint index and seed index (38.34\%, 5.22 and $8.81 \mathrm{gm}$ ) were recorded under $L_{3}$ and (38.25 \%, 5.33 and $\left.8.89 \mathrm{gm}\right)$ were achieved under $I_{3}$, respectively. The interaction between land leveling and cut-off irrigation had insignificant effect on lint percentage since it had high significant effect on lint index and seed index. The highest values of lint percentage (39.10\%), lint index (5.94) and seed index $(9.15 \mathrm{gm})$ were obtained with $I_{3}$ (cut-off irrigation at $\mathbf{8 0 \%}$ of furrow length) under $L_{3}(0.1 \%$ ground surface slope).

\section{Cotton fiber technological properties:}

Presented data in Table (5) clearly showed that the values of cotton fiber technological properties which were affected by land leveling and cut-off irrigation.

\section{Fiber fineness and fiber strength}

The results in Table (5) showed that the fiber fineness and fiber strength high significantly affected by land leveling and cut-off irrigation. The maximum values of fiber fineness and fiber strength (4.266 and 10.453$)$ were recorded under $L_{3}(0.1 \%$ ground surface slope) and (4.104 and 10.53) were achieved with $I_{3}$ (cut off irrigation at $\mathbf{8 0 \%}$ of furrow length) respectively. The interaction between land leveling and cut-off irrigation had significant effect on fiber fineness and while it had insignificant effect on fiber strength. The highest values of fiber fineness (5.007) and fiber strength (11.187) were obtained with $I_{3}$ (cut-off irrigation at $80 \%$ of furrow length) under $L_{3}(0.1 \%$ ground surface slope).
Length $2.5 \%$, length $50 \%$ and uniformity index:

The results in Table (5) indicated that the Length $2.5 \%$, length $50 \%$ and uniformity index highly significantly affected by land leveling and cut-off irrigation.

\section{Some water relations:}

Amount of seasonal applied water:

Presented data in Table (6) clearly showed that the values of cotton seasonal applied water were affected by land leveling and cut-off irrigation (as the average of two growing seasons). The highest values of seasonal water applied $\left(4200 \mathrm{~m}^{3}\right.$ fed $\left.^{-1}\right)$ were recorded under $L_{1}$ (traditional land leveling) and cut-off irrigation at $100 \%$ of furrow length, (traditional) respectively. It was noticed that the seasonal water applied was decreased with increasing cut off irrigation treatments under land leveling $\left(I_{2}\right.$ and $\left.I_{3}\right)$.

In comparison with cut-off irrigation at $100 \%$ of furrow length (no cut-off) under land leveling treatments. The highest values of water saving $\left(810 \mathrm{~m}^{3} \mathrm{fed}^{-1}\right.$ (20.71 \%)) were obtained with cut-off irrigation at $80 \%$ of furrow length and $L_{3}$ ( $0.10 \%$ ground surface slope). Based on the highest crop yield, water saving could be used for irrigating more crops and horizontal expansion in agriculture. The results are in a great harmony with those obtained by Abd-El-Fatah (2011), El-Ramady et al. (2013), Moursi et al. (2014), El-Hadidi et al. (2016), Zoghdan et al. (2019) and Kanannavar et al. (2020).

The maximum value of water saving was achieved in case of using gated pipes irrigation system under laser land leveling ( $0.1 \%$ slope) combined cut off irrigation at $80 \%$ of furrow length. 
Table 6. Seasonal applied water and water saving as affected by land leveling and cut-off irrigation treatments (average of two growing seasons).

\begin{tabular}{|c|c|c|c|c|c|}
\hline \multicolumn{2}{|l|}{ Treatments } & \multicolumn{2}{|c|}{ Seasonal water applied } & \multicolumn{2}{|c|}{ Water saving } \\
\hline $\begin{array}{l}\text { Land } \\
\text { leveling }\end{array}$ & $\begin{array}{l}\text { Cut-off } \\
\text { irrigation }\end{array}$ & cm fed f $^{-1}$ & $\mathrm{~m}^{3} \mathrm{fed}^{-1}$ & $\% \mathrm{~cm} \mathrm{fed}^{-1}$ & $\mathrm{~m}^{3} \mathrm{fed}^{-1}$ \\
\hline \multirow[b]{3}{*}{ L1 } & I1 & 100 & 4200 & - & - \\
\hline & 12 & 94.88 & 3985 & 5.12 & 215 \\
\hline & 13 & 92.26 & 3875 & 7.74 & 325 \\
\hline \multicolumn{2}{|c|}{ Mean } & 95.71 & 4020 & 6.43 & 270 \\
\hline \multirow[b]{3}{*}{ L2 } & I1 & 92.6 & 3889 & 7.4 & 311 \\
\hline & 12 & 85.95 & 3610 & 14.05 & 590 \\
\hline & 13 & 82.14 & 3450 & 17.86 & 750 \\
\hline \multicolumn{2}{|c|}{ Mean } & 86.9 & 3650 & 13.1 & 550 \\
\hline \multirow[b]{3}{*}{ L3 } & I1 & 86.3 & 3625 & 13.69 & 575 \\
\hline & 12 & 81.19 & 3410 & 18.8 & 790 \\
\hline & 13 & 79.29 & 3330 & 20.71 & 870 \\
\hline \multicolumn{2}{|l|}{ Mean } & 82.26 & 3455 & 17.73 & 745 \\
\hline
\end{tabular}

\section{Seasonal water consumptive use (Cu):}

The seasonal crop water consumptive use had the same trend as that of seasonal applied water. The mean values of seasonal water consumptive use are a direct function of the soil water status which already are affected by the amount of irrigation water applied.

Presented data in Table (6) showed that the highest mean values of seasonal water consumptive use $\left(2588 \mathrm{~m}^{3} \mathrm{fed}^{-1}\right.$ $(61.62 \mathrm{~cm})$ ) were recorded under $L_{1}$ (traditional land leveling) and cut-off irrigation at $100 \%$ of furrow length (as the average two growing seasons), respectively, compared with other treatments. Meanwhile, the lowest water consumptive use values $\left(2259 \mathrm{~m}^{3} \mathrm{fed}^{-1}\right.$ $(53.79 \mathrm{~cm}))$ were achieved with $\mathrm{L}_{3}$ (ground surface slope $0.1 \%$ ) and cut-off irrigation at $80 \%$ of furrow length $\left(I_{3}\right.$ treatment), respectively. It was observed that the values of seasonal water consumptive use were decreased with increasing cut-off irrigation under L2 and L3 treatments (dead level and ground surface slope $0.1 \%$ ), respectively. These results are in agreement with those obtained by Abd-El-Fatah (2011), ElRamady et al. (2013), Moursi et al. (2014), El-Hadidi et al. (2016), Mohamed, et al. (2017), Zoghdan et al. 2019 and Kanannavar et al. (2020).

Stored water in the effective root zone $\left(\mathrm{m}^{3} \mathrm{fed}^{-1}\right)$ :

The values of water stored in the effective root zone are presented in Table (7) revealed that the mean values of water stored in the effective rhizosphere were decreased by 3.34 and $6.92 \%$ with precision land leveling and ground surface slope $0.1 \%$ compared to traditional land leveling, while the lowest values was recorded with $l_{3}$ (cut-off irrigation at $80 \%$ of furrow length since it was $\left(2386 \mathrm{~m}^{3} \mathrm{fed}^{-1}\right)$ under $0.1 \%$ ground surface slope. 
Table 7. The seasonal water consumptive use and consumptive use efficiency as affected by different treatments (average two growing seasons).

\begin{tabular}{|c|c|c|c|c|c|c|}
\hline \multirow{3}{*}{\multicolumn{2}{|c|}{ Treatments }} & \multirow{2}{*}{\multicolumn{3}{|c|}{$\begin{array}{c}\text { Water consumptive use } \mathrm{m}^{3} \mathrm{fed}^{-1} \\
\text { Soil depth, } \mathrm{cm}\end{array}$}} & \multirow{3}{*}{$\begin{array}{c}\text { Total } \mathbf{m}^{3} \\
\text { fed }^{-1}\end{array}$} & \multirow{3}{*}{$\begin{array}{c}\text { Consumptive } \\
\text { use efficiency } \\
(\%)\end{array}$} \\
\hline & & & & & & \\
\hline & & $0-20$ & $20-40$ & $40-60$ & & \\
\hline & I1 & 1047 & 954 & 578 & 2588 & 61.62 \\
\hline & 12 & 1016 & 934 & 554 & 2504 & 62.84 \\
\hline L1 & 13 & 986 & 914 & 544 & 2444 & 63.06 \\
\hline $\mathrm{Me}$ & & 1016 & 934 & 559 & 2512 & 62.5 \\
\hline & I1 & 996 & 923 & 551 & 2470 & 63.48 \\
\hline & 12 & 953 & 898 & 533 & 2384 & 66.05 \\
\hline L2 & 13 & 918 & 873 & 518 & 2309 & 66.87 \\
\hline Me & & 956 & 898 & 534 & 2388 & 65.47 \\
\hline & I1 & 954 & 863 & 529 & 2346 & 64.54 \\
\hline & 12 & 914 & 848 & 519 & 2281 & 66.89 \\
\hline L3 & 13 & 901 & 843 & 515 & 2259 & 67.84 \\
\hline $\mathrm{Me}$ & & 923 & 851 & 521 & 2295 & 66.42 \\
\hline
\end{tabular}

While, the highest value is obtained from cut-off irrigation at $100 \%$ of furrow length which it was $\left(2678 \mathrm{~m}^{3} \mathrm{fed}^{-1}\right)$ under traditional land leveling. Results are in convenience with those achieved by Mohamed, et al 2017, Zoghdan et al. 2019 and Kanannavar et al. (2020).

\section{Irrigation efficiencies}

\section{Water application efficiency (Ea\%)}

Data in Table (8) showed that the highest value of water application efficiency (71.69 \%) was achieved from cut-off irrigation till $80 \%$ of furrow length underground surface slope $0.1 \%$ (the average two growing seasons), respectively, followed by cut-off irrigation at $90 \%$ of furrow length under the dead level (precision land leveling).

While, the lowest value of water application efficiency (63.76 \%) was resulted from cut-off irrigation at $100 \%$ of furrow length under $L_{1}$ (traditional land leveling), respectively. Also, it was noticed that the mean values of water application efficiency were increased with cut-off irrigation at $90 \%$ and $80 \%$ of furrow length under dead level (precision land leveling and ground surface slope $0.1 \%$. These results are some what agreed with those obtained by Mohamed, et al 2017, Zoghdan et al. 2019 and Kanannavar et al. (2020).

\section{Water consumptive use efficiency (Ecu, \%)}

Water consumptive use efficiency is a parameter which indicates the capability of plants to utilize the soil water stored in the effective root zone. Date in Table (7) showed that the highest value of Ecu $(67.84 \%)$ was recorded under cut-off irrigation at $80 \%$ of furrow length combined with ground surface slope 0.1 $\%$. On the other hand, the lowest value of Ecu (61.62 \%) was achieved from cut-off irrigation at $100 \%$ of furrow length under traditional land leveling. This finding is somewhat agreed with those obtained by Mohamed, et al 2017, Zoghdan et al. 2019 and Kanannavar et al. (2020). 
Water productivity (WP) and productivity of irrigation water (PIW) $\left(\mathrm{kg} \mathrm{m}^{-3}\right)$ :

Data in Table (9) showed the effect of land leveling and cut-off irrigation on water productivity and productivity of irrigation water; whereas the highest values for WP and PIW (0.655 and 0.435

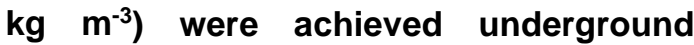
surface slope $0.1 \%\left(L_{3}\right)$ compared with $L_{1}$ and $L_{2}$, respectively. The highest values of WP and PIW 0.639 and $0.420 \mathrm{~kg} \mathrm{~m}^{-3}$ were achieved from cut-off irrigation at 90 and $100 \%$ of furrow length, respectively.

These results are in the same line with those obtained by Mohamed, et al (2017), Zoghdan et al. (2019) and Kanannavar et al. (2020).

Table 8. Stored water, water application efficiency and water distribution efficiency as affected by different treatments (average of two growing seasons).

\begin{tabular}{|c|c|c|c|c|c|c|}
\hline \multicolumn{2}{|c|}{ Treatments } & \multicolumn{4}{|c|}{ Stored water $\left(\mathrm{m}^{3} \mathrm{fed}^{-1}\right)$} & \multirow{3}{*}{$\begin{array}{l}\text { Water } \\
\text { application } \\
\text { efficiency(Ea\%) }\end{array}$} \\
\hline \multirow{2}{*}{$\begin{array}{l}\text { Land } \\
\text { leveling }\end{array}$} & \multirow{2}{*}{$\begin{array}{l}\text { Cut-off } \\
\text { irrigation }\end{array}$} & \multicolumn{3}{|c|}{ Soil depth, cm } & \multirow{2}{*}{$\begin{array}{l}\text { Total } \mathrm{m}^{3} \\
\text { fed }^{-1}\end{array}$} & \\
\hline & & $0-20$ & $20-40$ & $40-60$ & & \\
\hline \multirow[t]{3}{*}{ L1 } & I1 & 1102 & 979 & 597 & 2678 & 63.76 \\
\hline & 12 & 1037 & 949 & 584 & 2570 & 64.5 \\
\hline & 13 & 1032 & 946 & 581 & 2559 & 66.03 \\
\hline \multicolumn{2}{|c|}{ Mean } & 1057 & 958 & 587 & 2602 & 64.76 \\
\hline \multirow[t]{3}{*}{ L2 } & I1 & 1067 & 960 & 588 & 2615 & 67.23 \\
\hline & 12 & 1014 & 925 & 571 & 2510 & 69.52 \\
\hline & 13 & 969 & 895 & 557 & 2421 & 70.18 \\
\hline \multicolumn{2}{|c|}{ Mean } & 1017 & 927 & 572 & 2515 & 68.98 \\
\hline \multirow[t]{3}{*}{ L3 } & I1 & 997 & 915 & 564 & 2476 & 68.14 \\
\hline & 12 & 962 & 890 & 554 & 2406 & 70.43 \\
\hline & 13 & 950 & 886 & 550 & 2386 & 71.65 \\
\hline \multicolumn{2}{|c|}{ Mean } & 970 & 897 & 556 & 2423 & 70.07 \\
\hline
\end{tabular}

Table 9. Effect of land leveling and cut-off irrigation on cotton water productivity (WP, kg $\mathrm{m}^{-3}$ ) and productivity of irrigation water (PIW $\mathrm{kg} \mathrm{m}^{-3}$ ) (as average two seasons).

\begin{tabular}{|c|c|c|c|c|c|}
\hline Treatments & $\begin{array}{c}\text { Seed } \\
\text { cotton } \\
\text { yield } \\
\text { kentar I }_{\text {fed }} \text { f }^{-1} \\
\end{array}$ & $\begin{array}{c}\text { Water } \\
\text { applied } \\
\text { m }^{3} \text { fed }^{-1} \\
\end{array}$ & $\begin{array}{c}\text { Water } \\
\text { consumptive } \\
\text { use } \mathrm{m}^{3} \text { fed }^{-1}\end{array}$ & $\begin{array}{c}\text { Productivity } \\
\text { of irrigation } \\
\text { water (PIW kg } \\
\left.\mathbf{m}^{-1}\right)\end{array}$ & $\begin{array}{c}\text { Water } \\
\text { productivity } \\
(\text { WP kg m-1) }\end{array}$ \\
\hline L1 & 8.16 & 4020 & 2512 & 0.32 & 0.512 \\
\hline L2 & 8.97 & 3650 & 2389 & 0.387 & 0.591 \\
\hline L3 & 9.54 & 3455 & 2295 & 0.435 & 0.655 \\
\hline I1 & 8.27 & 3905 & 2468 & 0.334 & 0.528 \\
\hline 12 & 8.92 & 3668 & 2390 & 0.383 & 0.588 \\
\hline 13 & 9.48 & 3552 & 2337 & 0.42 & 0.639 \\
\hline
\end{tabular}




\section{REFERENCES}

Abd El-Fatah, I. M. (2011). Climate change impacts on maize under surface irrigation with gated pipes in North Nile Delta. M.Sc. thesis, Fac. Of Agric., Mansoura Univ., Egypt.

Aiad, M. A. (2007). Effect of some surface irrigation methods on soil salt distribution and crop productivity. Ph.D. Thesis. Fac. Agric., El-Mansoura Univ., Egypt.

Ali, M.H., M. R. Hoque, A. A. Hassan and A. Khair (2007). Effect of deficit irrigation on yield water productivity and economic returns of wheat agriculture water management, 92 (3): 151- 161

Amer, M. H., S. A. Abd El-Hafez and M. B. Abd El-Ghany (2017). Water saving In Irrigated Agriculture in Egypt (case studies and lesson Learned) L A P LAMBERT Academic Publishing .

Amira, H. R. Mohamed, E. E. Waseef, Y. S. Abdallah and A. M. Zedan (2017). Effect of gated pipes irrigation system on cotton yield and water use efficiency. Zagazig J. Agric. Res., 44 (2): $665-675$.

Anwar, A. A., W. Ahmad, M. T. Bhatti and Z. U. Hag (2016). The potential of precision surface irrigation in the Indvs basin irrigation system. Irrig. Sci., 34 (5): 379 - 396.

Basal, H., N. Dagdelen, A. Unay and E. Yilmaz (2009). Effect of deficit irrigation ratios on cotton (Gossypium hirsutum L.) and second crop corn (zea mays) in western Turkey. Agr water Manage. 82: 63 - 85.

Bautista, E.; A. J. Clemmens; T. S. Streilkoff and M. Niblack (2009). "Analysis of surface irrigation system with Win SRFR-Example Application". Agriculture water Management, Elsevier, 96: 1162 - 1169.

Blake, G. R. and, K. H. Hartage, 1986. Bulk Density,"In: A.Klute et al., Eds.,
Methods of soil analysis, part1, ASA and SSSA, Madison, pp: $363-375$.

Comez, K. A. and A. A. Gomez (1984). Statistical procedures for agriculture research. $2^{\text {nd }}$ Ed., John Willey and Sons, New York. USA.

Doorenbos, J. and W. D. Pruitt (1975). Crop water requirements, irrigation and drainage paper, 24 FAO, Rome.

Downy, L.A. (1970). water use by maize at three plant Densities, Paper 33, FAO, Rome

Eid, M., M. El-Tawel, M. A. M. Ibrahim, N. G. Ainer, M. A. Sherif, M. M. Wahha, K. K. Abd El-Mallak, E. A. El-khader and G. M. Gad El-Rab (1988). Controlled irrigation for field crops production within the context of improved farming systems at Minya. Agric. Res. Center. Soil, Water RES. Inst. Field Irrigation and Agroclimatology. Conf. 20-23 June. 1988, Giza, Egypt.

El-Ramady, H. R. M. A. Amer and M. A. Aiad (2013). Sustainable water and nutrient management use of land leveling, cut off irrigation and $\mathrm{N}$ fertilizer in wheat production. Journal of applied sciences Research 9 (3) 2232- 2243

El-Hadidi, E. M., M. M. Saied, Fatma M. Ghaly and R. M. Khalifa (2016). Assessing the effect of water discharge rates and cut-off irrigation on wheat production and some water relations at North Delta Region. J. Soil Sci. and Agric. Eng., Mansoura Univ., vol. 7 (6): 397 - 407.

El-Mowelhi, N. M., S. A. Abd El-Hafez, Somaya A. Hassanein and M. S. M. Abo Soliman (1996). Some aspects of water management for cotton at North Delta. Misr, J. Agric. Eng., Cairo Univ. Irri. Conf., 3 - 4 April.

El-Sanat, G. M. A. (2018). Improving irrigation efficiencies through different methods of land leveling and irrigation discharge under using gated pipes at 
North Delta. J. Soil Sci. and Agric. Eng., Mansoura Univ., vol. 9 (4): 143 148.

El-Shahawy, M. I. (2004). Some aspects of water management in furrow irrigation under cotton crop. J. Agric. Sci. Mansoura Univ., 29 (6): 3651 - 3660.

Hansen, V. W., O. W. Israelson and Q. E. Stringarm (1979). Irrigation principles and practices, $4^{\text {th }}$ ed. John Willey and Sons, New York.

James, L. G. (1988). Principles of farm irrigation system design. John Willey and Sons (ed.), New Yourk, pp. 543.

Jat, M. L., R. Gupta, P. Ramasundaram, M. K. Gathala, H. S. Sidhu, S. Singh, R. G. Singh, Y. S. Saharawat, V. Kumar, P. Chandna and J. K. Ladha (2009). Laser assisted precision land leveling: A potential technology for re-source conservation in irrigated intensive production system of Indo - Gangetic plains. Im: J. K. Ladha, et al., Eds., Integrated crop and Resource Management in the Rice - Wheat system of South Asia, International Rice Re-Search Institute, Los Banos: 223 - 238.

Jat, M. L., R. Gupta, Y. S. Saharawt and R. Khosla (2011). Layering precision land leveling and furrow irrigated raised bed planting productivity and input use efficiency of irrigation bread wheat in Indo-Gangetic plains. American Journal of Plant Sciences, 2: 578 - 588.

Jat, M. L., S. S. Pal, A. V. M. Subba Rao, K. Sirohi, S. K. Sharma and R. K. Gupta (2004). Laser land leveling: the precursor Technology for Resource Conservation in Irrigated Eco-system of India. Proceedings of the National Conference on Conservation Agriculture, New Delhi: 9 - 10.

Kanannavar, P. S., R. Vasantgouda, Kumar Lamani, B. C. Punitha and U. K. Shanawad (2020). Investigations on the effect of land leveling indices on soil moisture distribution in cotton field. International Journal of Current Microbiology and Applied Sciences 9 (5): 1344 - 1348.

Karam, F., L. Rafic, M. Randa, A. Daccache, $O$. Mounzer and $Y$. Rouphael (2006). Water use and lint yield response of drip irrigated cotton to length of season. Agr water Manage. 85: 287 - 295.

Michael, A. M. (1978). Irrigation theory and practice. Vikas publishing House, New Delhi, 1978.

Morris, M. R., A. Hussain, M. H. Gillies and $N$. J. Halloran (2015). Inflow rate and border irrigation performance. Agricultural Water Management. 155: $76-86$.

Moursi, E. A., Manal A. Aziz and Mona A. M. El-Mansoury (2014). Effect of length of irrigation run and nitrogen rates on productivity of wheat cultivars, some water relations and nitrogen content in heavy clay soils. J. Agric. Kafr. ElSheikh Univ., 40 (3): 630-658.

Page, A. L. R., H. Miller and D. R. Keeney (1982). Methods of soil analysis. Part 2: chemical and microbiological properties. $2^{\text {nd }}$ Edition, Agronomy Monograph, No. 9, ASA, CSSA, and SSSA, Madison.

Pettigrew, W.T. (2004). moisture deficit effects on cotton lint yield, yield components, and boll distribution. Agron J. 96: 377 - 383.

Piper, C. S. (1950). Soil and plant analysis. Inter science publication. New York Reddy, B.V.S; Reddy, P.S., Bidinger, $F$.

Rajput, T. B. S., N. Patel, G. Agrawal, 2004. Laser leveling tool to increase irrigation efficiency at field level. Journal of Agricultural Engineering, 41: $20-25$.

Saied, M. M. M. (1992). Effect of land leveling and irrigation discharge on 
cotton yield and irrigation efficiency. Ph.D. Thesis. Fac. Agric., El-Mansoura Univ., Egypt.

Semaika, m. R. and A. H. Rady (1987). Land leveling as an important water management operation and its impact on water resources in Egypt. International Committee Proceedings. Vol 11, 1987.

Streilkoff, T. S., Clemmens; M. El-Ansary and M. Awad (1999). Surface irrigation evaluation models: application to basins in Egypt. 42 (4): 1027 - 1036, Transactions of ASAE 1999 American Society of Agricultural Engineers.
Zoghdan, M. G., M. A. Aiad, M. M. A. Shabana and H. M. Abo elsoud (2019) Improvement of soil and water productivity for sugar beet under salt affected soils at north Nile delta Egypt -J- soil sci. and agric. Eng. Mansoura Univ., vol 10 (1): 41 - 50

Zonta, J. H., Z. N. Brandao, V. Safiatti, J. R. C. Bezexra and J. D. Medeiros (2016). Irrigation and nitrogen effects on seed cotton yield, water productivity and yield response factor in semi-arid environment. Australian Journal of Crop Science 10 (1): 118 126. 
تاثير تسوية التربة وطول جبهة الري علي محصول القطن وانتاجية وحدة المياه بمنطقة شمال وسط دلتا النيل

محمود ابوالفتوح محمود عياد (1)، عزة عبد السلام الهنداوى(2)

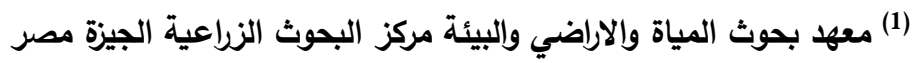

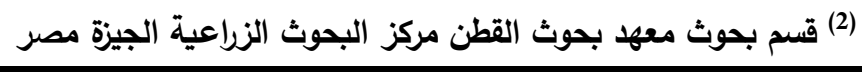

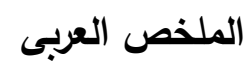

اجريت تجربة حقلية في الموسمين الزراعيين 2018 و2019 في مزرعة محطة البحوث الزراعية بسخا محافظة

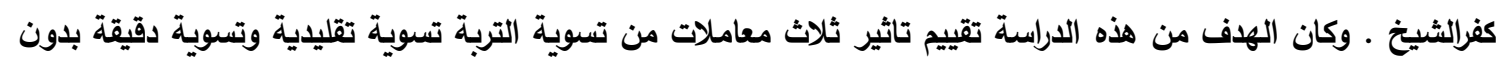

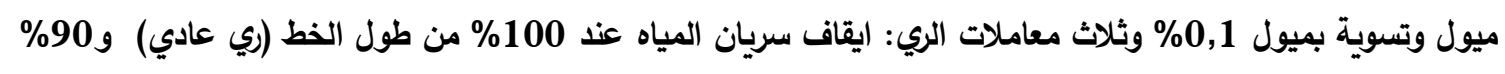

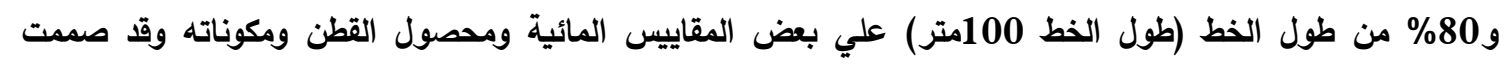

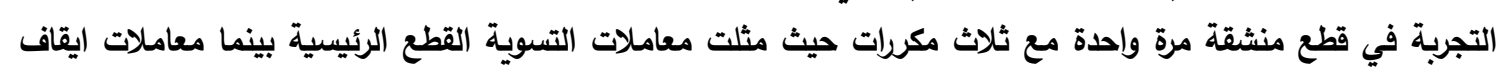
سريان المياه وضعت في القطع الثقية. ويمكن تلخيص اهم نتائج كما يلي : - كان لمعاملات التسوية ومعاملات ايقاف سريان مياه الري تاثيرا عالي المعنوية علي زيادة محصول القطن ومكوناته علي خواص الالياف التكنولوجية. - أمكن الحصول علي أعلي القيم لمحصول بذرة القطن ووزن اللوزة ومساحة الورقة وطول النبات ونسبة الثعر ودليل

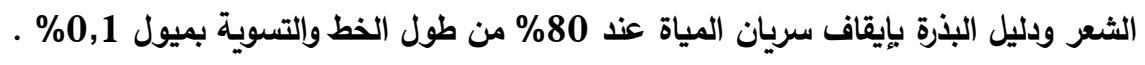

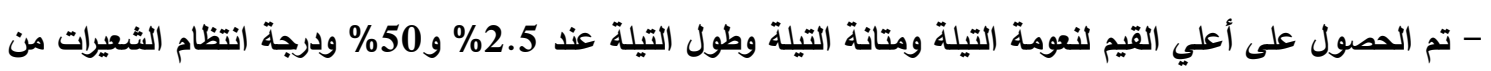

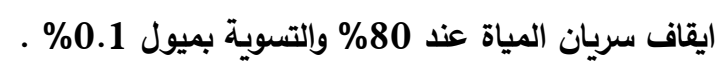

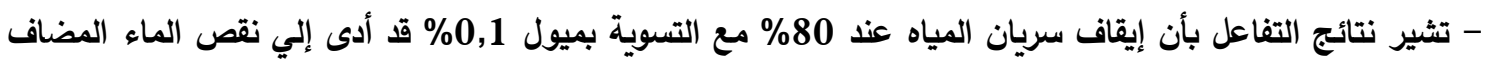

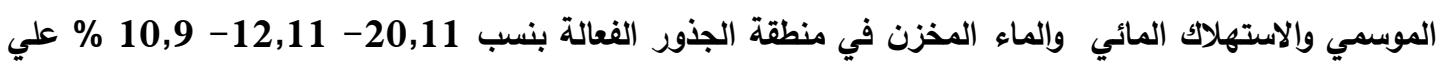

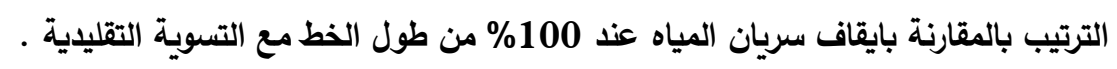

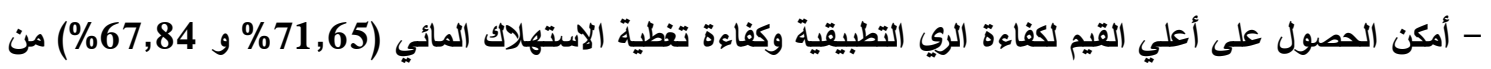

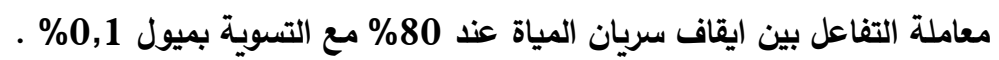

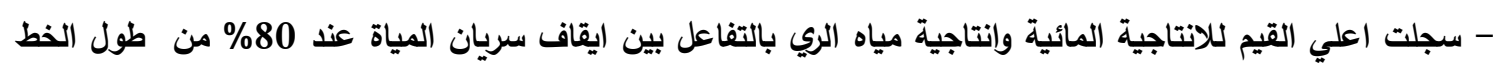
والتسوية بميول 0,1\% .

السادة المحكمين

أ.د/ سيد أبو الفتوح معهـ بحوث المياة والاراضي والبيئة مركز البحوث الزراعية الجيزة مصر أ.د/ محمود الاسوقى إبراهيم كلية الزراعة - جامعة المنوفية 